\title{
The USE OF ECONOMic Indicators AS A TOOL FOR PREDICTING S\&P 500 STOCK INDEX
}

\author{
Jan Dovolil \\ Technical University of Liberec, Faculty of Economics, Department of Economics, \\ Voroněžská 13, 46001 Liberec 1, Czech Republic \\ e-mail: jan.dovolil@tul.cz
}

\begin{abstract}
World organizations and businesses are struggling to best predict future economic developments. For example, the Organisation for Economic Co-operation and Development (OECD) constructed the Composite Leading Indicators (CLI) and the Conference Board organization (CB) created the Leading Economic Index (LEI) as a tool for prediction of the economy. This article aims to analyze the predictive ability of individual economic indicators, but not with respect to economic development, but in relation to the development of the S\&P 500 stock index. The result of the analysis of the indicators' predictive ability, i.e. leading, coincident and possible lagging of the indicator due to the development of the S\&P 500 stock index, is subsequently possible to use, for example, in the construction of a company's investment strategy, where the leading indicator serves as an indicator of the future development of the S\&P 500 stock index.
\end{abstract}

\section{Keywords}

S\&P 500 stock index; Economic indicators; Economic development; Prediction.

\section{Introduction}

Prediction of recession, swings and reversals in economic development has been such a strong motive for governments and managers that since about the 30's of the 20th century, increasingly apparent attempts to secure institutionary forecasting tools to ensure regular and comprehensive information about the economic outlook in the upcoming months can be seen in many Western countries. With the development of the appropriate tools of prediction, the forecasting methodology that seeks to synthesize the factors that accompany changes in economic development was also developed. [8]

One result of methodological experimentation is the construction of leading economic indexes that would bring together the partial economic indicators, which have repeatedly shown that their current behavior is closely correlated with changes in the future and report that economic development will change. [8] This study also describes the need for uniform statistical processing and seasonally adjusted data. Both the OECD and CB currently use all the above principles. Comincioli [2] and Umstead [13] show a positive correlation between the S\&P 500 stock index and economic development. In these studies, a positive correlation between the S\&P 500 stock index and economic development is demonstrated; thus the S\&P 500 can be marked as a leading indicator. Kubis and Cicarelli [9] suggest that the S\&P 500 stock index reaches average results as a tool for identifying the peaks and troughs of the economic cycle. The S\&P 500 stock index predicted peaks of the economic cycle with a $30 \%$ probability and troughs with $40 \%$ probability. The low predictive ability of peaks or troughs in this article, however, can be influenced by the S\&P 500 stock index data transformation. 
Today, the leading indexes are far beyond a mere experiment and they already monitor and predict the evolution of the economic cycle and demonstrate possible future risks in the economy. Czesaný and Jeřábková [3], Gyomai and Guidetti [5] demonstrated the effective use of leading indicators as economic indicators. Here, the economic indicator of Money Supply showed excellent predictive capabilities, predicting a peak of economic development of the economy with $75 \%$ probability and troughs with $63 \%$ probability. Apart from the ability to predict economic development, with the expansion of capital markets, there is an effort to predict the future development of stock indexes using leading indicators. Dovolil [4] and Leger [10] compare the CLI with the S\&P 500 stock index. The articles show a positive correlation between the CLI and S \& P 500. Within the article, however, CLI does not achieve the highest degree of correlation in advance, but with a delay. Based on these observations the composite CLI index can be marked as a lagging indicator due to the development of the S\&P 500 .

\section{$1 \quad$ Aims of the Article}

The article aims to analyze the predictive ability of individual economic indicators, but not with respect to economic development, but in relation to the development of the S\&P 500 stock index. The result of the analysis of the indicators' predictive ability, thus advance, overlapping, and possible delays of the indicator due to the development of the S\&P 500 stock index, can subsequently be applied, for example, in the construction of company's investment strategy, where the leading indicator serves as an indicator of the future development of the S\&P 500 .

The aim of this paper is to analyze the predictive power of economic indicators in relation to the development of the S\&P 500 stock index.

\section{$2 \quad$ Methodology and Methods}

The predictive capabilities of individual economic indicators in relation to the development of the S\&P 500 stock index are analyzed on the basis of historical data for the period from January 2007 to September 2014. Time series of leading indicators and S\&P 500 stock index are smoothed and cleaned using the Hodrick-Prescott (HP) filter.

The Hodrick-Prescott filter is one of the best known and most widely used de-trending methods. The filter was first described by Hodrick and Prescott [6]. Nowadays it is also used in the construction of the OECD CLI. In its original form the trend estimate is the result of optimization problem (1), (2).

$$
\begin{gathered}
y_{t}=\tau_{t}+c_{t} \\
\min \sum_{t}\left(y_{t}-\tau_{t}\right)^{2}+\lambda \sum_{t}\left(\tau_{t+1}-2 \tau_{t}+\tau_{t-1}\right)^{2}
\end{gathered}
$$

where

$y_{t}-$ initial series,

$\tau_{t}-$ trends,

$c_{t}-$ cyclical component,

$\lambda$ - HP filter parameter.

The initial $y_{t}$ series is decomposed into $\tau_{t}$, the trend component, and $c_{t}$, the cyclical component, with the objective being to minimize the distance between the trend and the 
original series and, at the same time, to minimize the curvature of the trend series. The tradeoff between the two goals is governed by the $\lambda$ parameter.

Subsequently, the leading indicators are correlated with the development of the S\&P 500 stock index using Spearman's correlation coefficient.

To evaluate the possibility of prediction of economic indicators, the correlation of time series and a subsequent analysis of the leaders, overlapping or delay is used in the time series of the economic indicator. Spearman's correlation coefficient is used to correlate the time series.

Spearman's correlation coefficient is a non-parametric method that uses the calculation of the order of values of monitored variables. This method can be used to describe any dependency, either linear or nonlinear. Spearman's correlation coefficient can be used to measure the strength of the relationship among these variables, where it cannot be expected to assume linearity of the relationship or normal distribution of the variables $x$ and $y$. Dependence variables can have both upward and downward character.

The calculation of Spearman's correlation coefficient $\left(r_{s}\right)$ is based on the order $(i)$ and the correlation couples $\left(i_{x}, i_{y}\right)$ are given by relation (3).

$$
r_{s}=1-\frac{6}{n \cdot\left(n^{2}-1\right)} \sum_{i=1}^{n}\left(i_{x}-i_{y}\right)^{2}
$$

where

$r_{s}$ - Spearman's correlation coefficient indicating the intensity of the relationship between the two monitored variables,

$i_{x}$ - the value of the time series $x$ in time $i$,

$i_{y}-$ the value of the time series $y$ in time $i$,

$n$ - number of correlation couples.

Methods of scientific work, particularly analysis, synthesis, comparison, deduction, induction, abduction, description and application of mathematical and statistical methods are used in the paper.

\section{$3 \quad$ Research}

This paper analyses the partial economic indicators with the development of the S \& P 500 stock index to identify leading, coincident and lagging economic indicators. The Standard \& Poor's 500 (S\&P 500) is an American stock market index based on the market capitalizations of 500 large companies. [12] Development of the S\&P 500 stock index is shown in Fig. 1.

\subsection{Economic Indicators}

Economic indicators can be grouped according to the timing of the turning point in the time series in relation to the reference series, which portrays the actual incidence of turning point. E.g. Kadeřábková and Žd'árek [7] divide them into three groups:

- Leading indicators are among the most observed, and allow predicting turning points in the economy with some time in advance before their actual implementation.

- Coincident indicators have been developed in parallel with the development of reference business cycle series including turning points (GDP can be included among the coincident indicators).

- Lagging indicators with a time lag replicate the reference series of economic development. 
Subsequently, the indicators are divided in terms of the cycle to:

- Cyclical indicators - their informational value increases with increasing economic activity and vice versa.

- Counter-cyclical indicators declining with the growth of economic activity and vice versa.

- Acyclic indicators do not match the cycle development.

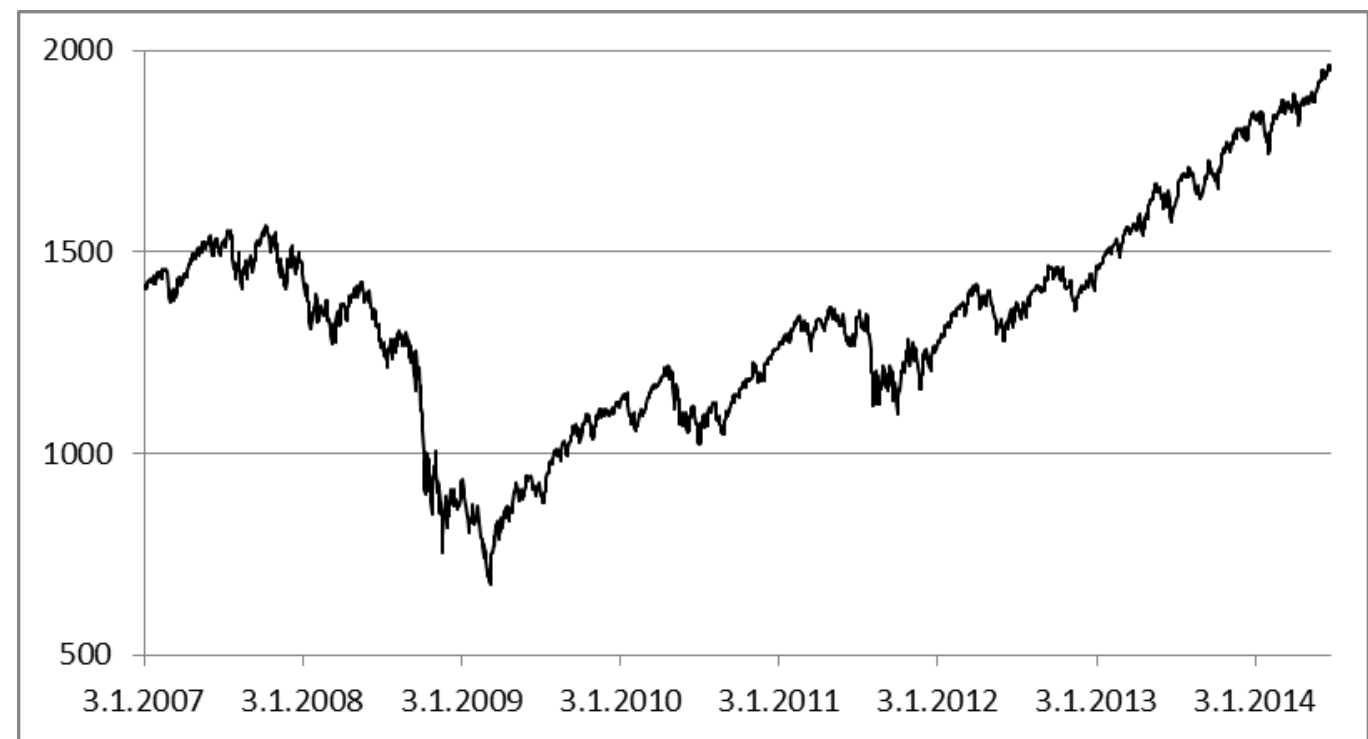

Source: Own from Yahoo[14]

Fig. 1: $\quad S \& P 500$ stock index

\subsection{Composite Indicators}

Organizations dealing with the predictions of economic development combine selected indicators divided into groups according to their timing in the form of aggregates, e.g. indexes. The reason for the formation of aggregates rather than observing time series of one indicator is the fact that the factors that influence the course of a time series may not be decisive for the cycle [11]. Using a larger number of indicators allows for smoothing part of volatility of the components of the index.

\subsubsection{Conference Board}

In the US, the Conference Board (CB) compiles and publishes a monthly composite index (LCI). Composite indexes are constructed by three groups of indicators differentiated according to timing of turning points in their time series. Leading Economic Index (LEI), Coincident Economic Index (CEI) and Lagging Economic Index (LAG) are constructed from four to ten indicators, some of which are published by state institutions (e.g. the central bank, the statistical offices), others are constructed and published by specialized agencies [1].

\subsubsection{OECD}

The OECD composite system of indicators (CLI) was created in the 70s of the 20th century and was designed to predict turning points in economic development. CLI and partial leading indicators are based on data available within the countries involved in the index and are used for short-term forecasts of changes in the direction of the economy (6 to 12 months). For each country, slightly different time series of leading indicators and types of leading indicators in the index are chosen [5]. 
Within this paper, partial economic indicators of United States which have or have not been incorporated into the composite leading index CLI or LEI are selected and subsequently analyzed:

- New residential sale

- New Residential Construction

- Retail Trade and Food Services, ex Auto

- Sales for Auto and Other Motor Vehicles

- Manufacturing Inventories

- Durable Goods Orders

- Purchasing Managers Index, PMI

- Unemployment Rate - Manufacturing

- Labor - Average weekly hours

- Inflation

- Money supply M2

- Mortgage fix rate -30 years

- Interest rate spread, 10-year Treasury bonds less federal funds

\subsection{Economic Indicators Correlated with the S\&P 500 Stock Index}

The predictive capabilities of individual economic indicators in relation to the development of the S\&P 500 stock index are analyzed on the basis of historical data for the period from January 2007 to September 2014. The indicators reference series are analyzed due to date of publishing the indicator data. The date of the disclosure of indicator data is around $1-1.5$ months later in relation to the time period. For example data for January are being published in late February or in mid-March. Time series are correlated when the indicator value is published.

Tab. 1: Economic indicator of United States correlated with the S\&P 500 stock index

\begin{tabular}{|l|c|c|}
\hline \multirow{2}{*}{$\begin{array}{l}\text { Economic indicator of United States } \\
\text { correlated with the S\&P 500 stock index }\end{array}$} & \multicolumn{2}{|c|}{$\begin{array}{c}\text { The highest Spearman's correlation } \\
\text { coefficient }\end{array}$} \\
\cline { 2 - 3 } Value & $\begin{array}{c}\text { Time } \\
\text { Leading/Coincident/Lagging } \\
\text { Indicator) }\end{array}$ \\
\hline New Residential Sale & 0.692 & Lagging - 10 months \\
\hline New Residential Construction & 0.860 & Lagging - 5 months \\
\hline Retail Trade and Food Services, ex Auto & 0.778 & Leading - 1 month \\
\hline Sales for Auto and Other Motor Vehicles & 0.991 & Coincident - 0 month \\
\hline Manufacturing Inventories & 0.776 & Lagging - 5 months \\
\hline Durable Goods Orders & 0.965 & Lagging - 5 months \\
\hline Purchasing Managers Index, PMI & 0.860 & Lagging - 1 month \\
\hline Unemployment Rate - Manufacturing & -0.940 & Lagging - 7 months \\
\hline Labor - Average weekly hours & 0.831 & Lagging - 4 months \\
\hline Inflation & -0.948 & Leading - 21 months \\
\hline Money supply M2 & 0.998 & Lagging - 1 month \\
\hline Mortgage fix rate - 30 years & -0.980 & Leading - 24 months \\
\hline $\begin{array}{l}\text { Interest rate spread, 10-year Treasury bonds } \\
\text { less federal funds }\end{array}$ & -0.587 & Lagging - 6 months \\
\hline
\end{tabular}

Source: Own 
Economic indicators data correlated with the S\&P 500 stock index data is shifted to each reference series. The aim of computation is to find the highest Spearman's correlation coefficient. The highest Spearman's correlation coefficient indicates the closest dependence between reference series of economic indicator and S\&P 500 stock index. Based on the highest Spearman's correlation coefficient it is possible to identify the predictive ability of individual economic indicators. The detail of each individual economic indicator, the value of the highest Spearman's correlation coefficient and the predictive ability can be seen in Tab. 1 .

All analyzed economic indicators are cyclical with respect to the S\&P 500 stock index, except for Inflation, the Unemployment Rate - Manufacturing, Mortgage fix rate - 30 years, and Interest rate spread, which are counter-cyclical.

Inflation and Mortgage fix rate - 30 years rate reach the highest inverse correlation coefficient with 21 and 24 months of advance notice. However, this is a very long interval within the reporting period, and therefore; the data may be biased due to the time series shortening. For this reason, the relationship between the inflation and the S\&P 500 needs to be tested for longer periods of time. The economic indicator Retail Trade and Food Services, ex Auto is another indicator which indicates predictive ability of the indicator. The timeline of the prediction ability of this indicator is 1 month. Spearman's correlation coefficient obtains the 0.778 value. The value of Spearman's correlation coefficient indicates a close relationship between reference series of the S\&P 500 stock index and the economic indicator Retail Trade and Food Services, ex Auto. Coincident indicator was only one - Sales for Auto and Other Motor Vehicles. The value of Spearman's correlation coefficient 0.991 indicates a deep relationship among reference series.

\section{Conclusion}

From the correlation analysis of economic indicators, four sub-economic indicators showed the highest value of the Spearman correlation coefficient in advance. However three of them have a very long interval. The economic indicator Retail Trade and Food Services, ex Auto peaked Spearman's correlation coefficient 0.778 one month in advance. Other economic indicators showed the highest degree of tightness with variously long delays in relation to the S\&P 500. This fact is also due to the delay in data publication of partial indicators. On average, the delay in the disclosure of data indicator is around $1-1.5$ months. Data for January are being published in late February or in mid-March. The highest degree of dependence with the development of the S\&P 500 stock index is reported for the retail sales economic indicator of the Money supply M2 (Spearman's correlation coefficient 0.998).

The result of the analysis of the indicators' predictive ability, i.e. leading, coincident, and possible lagging of the indicator due to the development of the S\&P 500 stock index, is subsequently possible to use, for example, in the construction of a company's investment strategy, where the leading indicator serves as an indicator of the future development of the S\&P 500 stock index. The results of correlation analysis confirm the statements that the actual S\&P 500 stock index is a leading indicator, see Comincioli [2] and Umstead [13].

\section{Literature}

[1] CONFERENCE BOARD. U. S.: Business Cycle Indicators. [online]. 2015. [accessed 2015-04-22]. Available from WWW: http://www.conferenceboard.org/pdf_free/press/TechnicalPDF_5393_1424340004.pdf

[2] COMINCIOLI, B.: The Stock Market as a Leading Indicator: An Application of Granger Causality. University Avenue Undergraduate. Journal of Economic. 1977, Vol. 1, ISSN 1617-7134. 
[3] CZESANÝ, S.; JEŘÁBKOVÁ, Z.: Metoda konstrukce kompozitních indikátorů hospodářského cyklu pro českou ekonomiku. Statistika. 2009, No. 3, pp. 21-31. ISSN 0322-788x

[4] DOVOLIL, J.: Predikce vývoje akciového indexu S\&P500 na základě kompozitního předstihového indikátoru CLI US OECD. Sborník př́spěvků $z V$. mezinárodní Masarykovy konference pro doktorandy a mladé vědecké pracovníky. Hradec Králové: Magnanimitas, 2014. pp. 1156-1163. ISBN 978-80-87952-07-8.

[5] GYOMAI, G.; GUIDETTI, E.: OECD system of composite leading indicators. OECD [online]. 2012. [accessed 2015-04-21]. Available from WWW: http://www.oecd.org/std/41629509.pdf

[6] HODRICK, R.; PRESCOTT, C.: Postwar U.S. Business Cycles: An Empirical Investigation. Journal of Money, Credit, and Banking. 1997. pp. 1-16. ISSN 15384616.

[7] KADEŘÁBKOVÁ, A.; ŽĎÁREK, V.: Makroekonomická analýza. Praha: VŠEM, 2006. 294 p. ISBN 978-80-86730-05-9.

[8] KLEIN, A.; MOORE, H.: The Leading Indicators Approach to Economic Forecasting. [online]. Journal of Forecasting. 1982. [accessed 2015-04-25]. Available from WWW: http://www.nber.org/papers/w0941.pdf

[9] KUBIS, A.; CICARELLI, J.: Research in Applied Economics. Revisiting the Leading Economic Indicators. 2012, Vol. 4, No. 4, ISSN 1948-5433.

[10] LEGER, T.: The impact of slowing global growth on us profits payrolls and stocks. Seeking Alpha [online]. 2012. [accessed 2015-04-22]. Available from WWW: http://seekingalpha.com/article/642141-the-impact-of-slowing-global-growth-on-u-sprofits-payrolls-and-stocks

[11] SOUČEK, E.: Hospodářské barometry - teorie a praxe [online]. 2000 [accessed 201504-21]. Available from http://dspace.upce.cz/bitstream/10195/32373/1/CL90.pdf

[12] S\&P 500. In: Wikipedia. [encyclopedia online]. Wikimedia Foundation Inc., updated 26 August 2015, at 18:56. [accessed 2015-09-07]. Available from WWW: https://en.wikipedia.org/wiki/S\%26P_500

[13] UMSTEAD, A.: Forecasting stock market pricing. The Journal of Finance, 1977, Volume 32, Issue 2, 427-441 p, ISSN 1540-6261.

[14] YAHOO: S\&P 500. [online]. 2014. [accessed 2015-04-22]. Available from WWW: http://www.yahoo.com 


\section{VYUŽITÍ EKONOMICKÝCH INDIKÁTORŮ JAKO NÁSTROJ PREDIKCE VÝVOJE AKCIOVÉHO INDEXU S\&P 500}

Světové organizace a podniky se snaží co nejlépe predikovat budoucí vývoj ekonomiky. Organizace pro hospodářskou spolupráci a rozvoj (OECD) zkonstruovala systém Composite Leading Indicators (CLI) a organizace Conference Board (CB) vytvořila Leading Economic Index (LEI) jako nástroj predikce vývoje ekonomiky. Př́spěvek si klade za cíl analyzovat predikční schopnosti dílčích ekonomických indikátorů - nikoliv však vzhledem k vývoji ekonomiky, ale vzhledem k vývoji akciového indexu S\&P 500. Výsledek analýzy predikčních schopností indikátorů, tedy předstih, souběh a př́padné zpoždění indikátoru vzhledem $\mathrm{k}$ vývoji akciového indexu S\&P 500, je následně možné využít např́klad př̀i konstrukci investiční strategie podniku, kde předstihový ukazatel slouží jako indikátor budoucího vývoje akciového indexu S\&P 500.

\section{DIE VERWENDUNG VON WIRTSCHAFTSINDIKATOREN ALS INSTRUMENT ZUR VORHERSAGE DER ENTWICKLUNG DES AKTIENINDEX S\&P 500}

Die Weltorganisationen und -unternehmen bemühen sich, die zukünftige Entwicklung der Wirtschaft bestens vorherzusagen. Die Organisation für wirtschaftliche Zusammenarbeit und Entwicklung (OECD) hat das System Composite Leading Indicators (CLI) konstruiert, und die Organisation Conference Board (CB) hat den Leading Economic Index (LEI) als Instrument zum Vorhersagen der Entwicklung der Wirtschaft entworfen. Das Ziel des Beitrags besteht in der Analyse der prädiktiven Fähigkeiten der einzelnen ökonomischen Indikatoren, jedoch nicht in Bezug auf die Entwicklung der Ökonomik, sondern in Bezug auf die Entwicklung des Aktienindexes S\&P 500. Das Ergebnis der Analyse der prädiktiven Fähigkeiten der Indikatoren, also den Vorsprung, den Gleichlauf und die eventuelle Verzögerung eines Indikatoren gegenüber der Entwicklung des Aktienindexes S\&P 500, kann man nachfolgend zum Beispiel beim Konstruieren der Investitionsstrategie eines Unternehmens verwerten, wobei der Indikator des Vorsprungs als Indikator der zukünftigen Entwicklung des Aktienindexes S\&P 500 dient.

\section{WYKORZYSTANIE WSKAŹNIKÓW EKOOMICZNYCH JAKO NARZĘDZIA DO PROGNOZOWANIA ROZWOJU INDEKSU GIEŁDOWEGO S\&P 500}

Organizacje światowe i przedsiębiorstwa starają się jak najlepiej przewidzieć rozwój gospodarki w przyszłości. Organizacja Współpracy Gospodarczej i Rozwoju (OECD) stworzyła system Composite Leading Indicators (CLI) a organizacja Conference Board (CB) opracowała Leading Economic Index (LEI) jako narzędzie do prognozowania rozwoju gospodarczego. Celem artykułu jest przeprowadzenie analizy zdolności prognostycznej poszczególnych wskaźników ekonomicznych, jednak nie w odniesieniu do rozwoju gospodarki, ale w stosunku do kształtowania się indeksu giełdowego S\&P 500. Wyniki analizy zdolności prognostycznej wskaźników, a zatem wyprzedzenie, zbieżność i ewentualne opóźnienie wskaźnika wobec rozwoju indeksu giełdowego S\&P 500, można później wykorzystać przykładowo w ramach budowania strategii inwestycyjnej firmy, gdzie wskaźnik wyprzedzający służy jako wskaźnik przyszłego rozwoju indeksu giełdowego S\&P 500. 